\title{
Experimental Study on Impact of Heating Temperature and Heating Rate during Carbonization of Woody Biomass
}

\author{
Haizhen Huang ${ }^{*}$, Zhenwei Jiao, Zhenyang Shu and Yaoguo Zeng \\ Thermal energy department, Jilin university, Changchun, China \\ ${ }^{*}$ Corresponding author
}

\begin{abstract}
Carbonization is the thermal treatment technique performed in an inert atmosphere, which aims to improve the fuel properties. In this study, the selected woody biomass of koraiensis bark (KB) was carbonized under three heating levels $\left(5^{\circ} \mathrm{C} / \mathrm{min}, 10^{\circ} \mathrm{C} / \mathrm{min}, 20^{\circ} \mathrm{C} / \mathrm{min}\right)$ at heating temperature from $200^{\circ} \mathrm{C}$ to $600{ }^{\circ} \mathrm{C}$.The yields of fixed carbon, charcoal yield rate, energy yield rate, mass energy density and quality of charcoal were analyzed. Considering all the evaluation indexes, $\mathrm{KB}$ carbonized at $450{ }^{\circ} \mathrm{C}$ under heating rate of $10^{\circ} \mathrm{C} / \mathrm{min}$ matched each index best under the preset experimental conditions.
\end{abstract}

Keywords- biomass; carbonization; heating rate; heating temperature; energy yield

\section{INTRODUCTION}

China has become the second largest energy consumer in the world, it is necessary to ensure rational utilization of energy and protect environment. Biomass energy shows a promising prospect among different renewable energies resources [1-2]. Many technologies have been proposed including biomass briquetting or pelletizing, biochar, torrefaction, gasification or hydrothermal processing etc. Carbonization is a process with a thermal treatment in an inert atmosphere while producing charcoal from biomass pellets, which improves the thermochemical properties of biomass in heating value, energy density and combustion efficiency[3-9]. It provides the possibility of biomass energy utilization and extension, especially in rural area in China.

In order to control the yield and quality of carbonized biomass effectively, the sound understanding of the carbonization process is therefore very necessary. In this paper, the impact of final heating temperature and heating rate on carbonization process of woody biomass was investigated.

\section{EXPERIMENTAL METHODS}

\section{A. Materials and Samples}

The selected biomass material is koraiensis bark (KB), which is an abundant biomass resources in China. The cylindric biomass pellet samples prepared for carbonization process were made via a self-heating hydraulic mold machine at the mold temperature of $180^{\circ} \mathrm{C}$ and mold pressure of $25 \mathrm{MPa}$ under which conditions the pellets could meet the requirements of carbonization. Each sample was $25 \mathrm{~mm}$ in diameter, $10 \mathrm{~g}$ in mass and about $1.04 \sim 1.12 \mathrm{~g} / \mathrm{cm}^{3}$ in mass density.

\section{B. Experimental Device}

The proximate analysis and calorific values of samples were performed by automatic industrial analyzer (SDTGA3000) and automatic calorimeter (SDACM-3000) respectively. Carbonization of samples were conducted in the experimental device shown in Figure I. A cylindric electric oven with $130 \mathrm{~mm}$ interior diameter and $3 \mathrm{~kW}$ rated power was used to heat the samples during carbonization process. Both the heating rate and the chamber temperature were controlled by an PID controller (Yuguang AI518P).

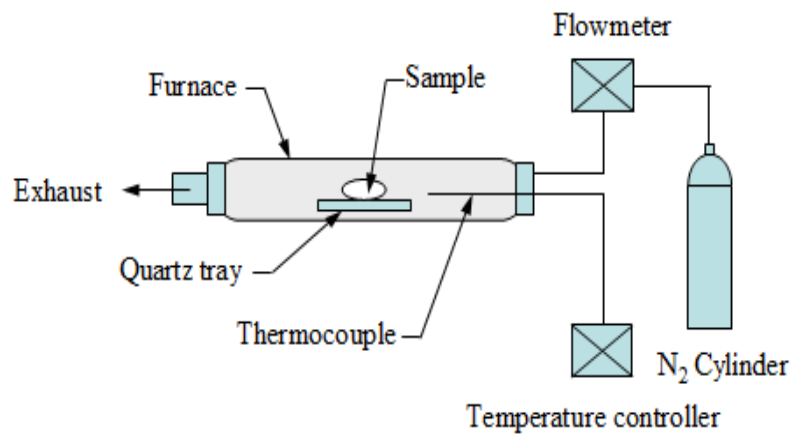

FIGURE I. SCHEMATIC DIAGRAM OF EXPERIMENTAL DEVICE OF CARBONIZATION PROCESS

\section{Experiments}

The experiment was conducted under inert atmosphere of nitrogen gas. First put the sample into the middle part of the furnace chamber, then pure nitrogen gas flowed through at the flow rate of $3 \mathrm{~L} / \mathrm{min}$ in order to purge the chamber before carbonization process and continuously flowed through during the process. When samples were heated at heating rate of $5^{\circ} \mathrm{C} / \mathrm{min}, 10^{\circ} \mathrm{C} / \mathrm{min}, 20^{\circ} \mathrm{C} / \mathrm{min}$ to the preset final temperature, after keeping the final temperature for $30 \mathrm{~min}$, heating process would be stopped, but the nitrogen gas continued flowing through until the chamber temperature declined to $100^{\circ} \mathrm{C}$. Then after the sample's temperature declined to room temperature, it would be sealed in a plastic bag with desiccant to get ready for the thermal property test and analysis. The naming rule of each examined sample was defined. For example, a sample heated to final temperature of $200^{\circ} \mathrm{C}$ at $5^{\circ} \mathrm{C} / \mathrm{min}$ heating rate is $\mathrm{KB}-200-5$. 


\section{RESULTS AND DISCUSSION}

\section{A. Defination of Quality Index of Carbonization Process}

Biomass is mainly composed of hemicellulose, cellulose and lignin [10]. All of the three components will conduct thermal degradation and yield different gaseous products while being heated under inert atmosphere. That process is pyrolysis, the gaseous products are volatile, the remained part of biomass is charcoal. Parameters used to described the quality indexes of charcoal includes proximate analysis, high calorific value (HCV), charcoal yield rate (CYR), energy yield rate (EYR) and mass energy density (MED), which are defined as follows:

$$
\eta_{\mathrm{m}}=\left(\mathrm{m}_{2} / \mathrm{m}_{1}\right) \times 100 \%
$$

$$
\eta_{\mathrm{e}}=\eta_{\mathrm{m}}\left(\mathrm{Q}_{2} / \mathrm{Q}_{1}\right) \times 100 \%
$$

$$
\eta_{\mathrm{d}}=\eta_{\mathrm{e}} / \eta_{\mathrm{m}}
$$

$\eta_{\mathrm{m}}$ - charcoal yield rate, $\% ; \eta_{\mathrm{e}}$ - energy yield rate, $\% ; \eta_{\mathrm{d}}-$ mass energy density; $\mathrm{m}_{1}, \mathrm{~m}_{2}$ - mass of samples before and after carbonization, g; $\mathrm{Q}_{1}, \mathrm{Q}_{2}$ - high calorific value $(\mathrm{HCV})$ before and after carbonization on dry basis, $\mathrm{MJ} / \mathrm{kg}$.

Table I shows the proximate analysis on dry basis, high calorific values, charcoal yield rate, energy yield rate and mass energy density of samples carbonized at various conditions.

\section{B. Analysis of Impact Factors on Charcoal Quality}

\begin{tabular}{|c|c|c|c|c|c|c|c|}
\hline Samples & $\begin{array}{c}\text { Volatile } \\
\text { (\%) }\end{array}$ & $\begin{array}{l}\text { Ash } \\
(\%)\end{array}$ & $\begin{array}{c}\text { Fixed } \\
\text { crabon } \\
(\%)\end{array}$ & $\begin{array}{c}\text { HCV } \\
\text { (MJ/kg) }\end{array}$ & $\begin{array}{c}\text { CYR } \\
(\%)\end{array}$ & $\begin{array}{c}\text { EYR } \\
(\%)\end{array}$ & MED \\
\hline RAW KB & 76.47 & 6.26 & 17.27 & 20.24 & 100 & 100 & 1 \\
\hline KB-200-5 & 70.03 & 6.65 & 18.33 & 20.52 & 90.5 & 91.71 & 1.01 \\
\hline KB-250-5 & 68.31 & 7.65 & 21.1 & 20.85 & 85.91 & 88.46 & 1.03 \\
\hline KB-300-5 & 52.23 & 11.83 & 32.61 & 22.66 & 68.17 & 76.28 & 1.12 \\
\hline KB-350-5 & 41.52 & 14.87 & 41.01 & 23.02 & 58.3 & 66.27 & 1.14 \\
\hline KB-400-5 & 30.11 & 17.62 & 48.58 & 23.18 & 50.44 & 57.74 & 1.14 \\
\hline KB-450-5 & 24.86 & 19.39 & 53.47 & 23.45 & 46.11 & 53.40 & 1.16 \\
\hline KB-500-5 & 20.59 & 20.19 & 55.69 & 23.9 & 43.14 & 50.92 & 1.18 \\
\hline KB-550-5 & 20.05 & 20.42 & 56.33 & 23.9 & 41.54 & 49.03 & 1.18 \\
\hline KB-600-5 & 14.96 & 22.04 & 60.77 & 24.02 & 38.15 & 45.25 & 1.19 \\
\hline KB-200-10 & 69.43 & 7.05 & 19.46 & 20.67 & 88.41 & 90.24 & 1.02 \\
\hline KB-250-10 & 63.6 & 8.65 & 23.87 & 21.04 & 81.95 & 85.15 & 1.04 \\
\hline KB-300-10 & 51.09 & 12.13 & 33.45 & 22.44 & 67.64 & 74.96 & 1.11 \\
\hline KB-350-10 & 44.49 & 13.78 & 37.99 & 22.95 & 60.19 & 68.22 & 1.13 \\
\hline KB-400-10 & 35.51 & 15.89 & 43.81 & 23.41 & 51.89 & 59.99 & 1.16 \\
\hline KB-450-10 & 30.24 & 17.35 & 47.84 & 23.77 & 48.63 & 57.08 & 1.17 \\
\hline KB-500-10 & 24.37 & 18.75 & 51.71 & 23.69 & 43.68 & 51.10 & 1.17 \\
\hline KB-550-10 & 21.41 & 19.41 & 53.52 & 23.81 & 41.6 & 48.91 & 1.18 \\
\hline KB-600-10 & 18.08 & 20.52 & 56.61 & 23.61 & 40.19 & 46.86 & 1.17 \\
\hline KB-200-20 & 67.13 & 7.72 & 21.3 & 20.37 & 86.12 & 86.63 & 1.01 \\
\hline KB-250-20 & 57.42 & 10.23 & 28.23 & 20.59 & 76.32 & 77.60 & 1.02 \\
\hline KB-300-20 & 46.68 & 13.26 & 36.59 & 22.45 & 61.26 & 67.92 & 1.11 \\
\hline KB-350-20 & 41 & 14.66 & 40.45 & 22.49 & 60.29 & 66.96 & 1.11 \\
\hline KB-400-20 & 30.31 & 17.33 & 47.8 & 22.54 & 49.62 & 55.23 & 1.11 \\
\hline KB-450-20 & 28.26 & 17.22 & 49.48 & 22.95 & 46.15 & 52.30 & 1.13 \\
\hline KB-500-20 & 24.12 & 18.69 & 51.56 & 23.36 & 43.58 & 50.27 & 1.15 \\
\hline KB-550-20 & 20.55 & 19.75 & 54.47 & 23.85 & 40.01 & 47.12 & 1.18 \\
\hline KB-600-20 & 19.8 & 19.66 & 54.24 & 23.94 & 39.07 & 46.19 & 1.18 \\
\hline
\end{tabular}

1) Impact of final heating temperature

TABLE I. PROXIMATE ANALYSIS AND YIELDS OF KB CHARCOAL AT VARIOUS CONDITIONS 
Figure II shows the yields of different products during the carbonization process of $\mathrm{KB}$ at different final heating temperature respectively after holding time of $30 \mathrm{~min}$.

Figure II (a) shows the yields at different temperature in the range from $200^{\circ} \mathrm{C}$ to $600^{\circ} \mathrm{C}$ at heating rate of $5^{\circ} \mathrm{C} / \mathrm{min}$. The yield of the $\mathrm{FC}$ increased with the increase in the heating temperature range from $18.63 \%$ to $60.77 \%$. It showed a faster increase before heating temperature of $400^{\circ} \mathrm{C}$ than after $400^{\circ} \mathrm{C}$. This is maily because most volatile within the $\mathrm{KS}$ released quickly under $400^{\circ} \mathrm{C}$, thus made the mass persentage of $\mathrm{FC}$ yield increased quickly. It became harder to be released for the rest of volatile, so that FC yield increased a bit slowly after final heating temperature of $400{ }^{\circ} \mathrm{C}$. The $\mathrm{HCV}$ showed an increasing trend within the preset temperature range from $20.85 \mathrm{MJ} / \mathrm{kg}$ to $22.66 \mathrm{MJ} / \mathrm{kg}$ with charateristics of a peak increase between $250^{\circ} \mathrm{C}$ and $300^{\circ} \mathrm{C}$. The reason for this rapid change of $\mathrm{HCV}$ is mainly because the sharp decrease of volatile from $68.31 \%$ to $52.23 \%$ in this temperature range, while FC increased from $21.1 \%$ to $32.61 \%$. The HCV increased from $20.52 \mathrm{MJ} / \mathrm{kg}$ to $24.02 \mathrm{MJ} / \mathrm{kg}$ within the the heating temperature range. Both CYR and EYR showed a downward trend within the preset temperature range. Before final heating temperature of $250^{\circ} \mathrm{C}$, both $\mathrm{CYR}$ and $\mathrm{EYR}$ showed similar downward trends and values. At the final heating temperature range of $250^{\circ} \mathrm{C}$ to $600^{\circ} \mathrm{C}$, it still remained the similar downward trends but with a difference between values. CYR decreased from $90.5 \%$ to $38.15 \%$, EYR decreased from $91.71 \%$ to $45.25 \%$ within the preset temperature range.

Figure II (b) and (c) shows the yields at different temperature in the range of $200-600^{\circ} \mathrm{C}$ at heating rate of $10^{\circ} \mathrm{C} / \mathrm{min}$ and $20^{\circ} \mathrm{C} / \mathrm{min}$ respectively. The results showed similar trends like at heating rate of $5^{\circ} \mathrm{C} / \mathrm{min}$ with different characteristic values. At the heating rate of $10^{\circ} \mathrm{C} / \mathrm{min}$, the yield of the FC increased from $19.46 \%$ to $56.61 \%$ within the heating temperature range. The $\mathrm{HCV}$ with a peak increase between $250^{\circ} \mathrm{C}$ and $300^{\circ} \mathrm{C}$ changed from $21.04 \mathrm{MJ} / \mathrm{kg}$ to $22.44 \mathrm{MJ} / \mathrm{kg}$, the volatile changed from $63.6 \%$ to $51.09 \%$, while FC increased from $23.87 \%$ to $33.45 \%$. The HCV increased from $20.67 \mathrm{MJ} / \mathrm{kg}$ to $23.61 \mathrm{MJ} / \mathrm{kg}$ within entire heating temperature range, while CYR decreased from $88.41 \%$ to $40.19 \%$, EYR decreased from $90.24 \%$ to $46.86 \%$. At heating rate of $20^{\circ} \mathrm{C} / \mathrm{min}$, the yield of $\mathrm{FC}$ increased within entire heating temperature range from $21.3 \%$ to $54.24 \%$. The HCV changed from $20.59 \mathrm{MJ} / \mathrm{kg}$ to $22.45 \mathrm{MJ} / \mathrm{kg}$ with a peak increase between $250^{\circ} \mathrm{C}$ and $300^{\circ} \mathrm{C}$, along with the volatile changed from $57.42 \%$ to $46.68 \%$, while FC increased from $28.23 \%$ to $36.59 \%$. The HCV increased from $20.37 \mathrm{MJ} / \mathrm{kg}$ to $22.94 \mathrm{MJ} / \mathrm{kg}$ within entire heating temperature range, while CYR decreased from $86.12 \%$ to $39.07 \%$, EYR decreased from $86.63 \%$ to $44.26 \%$.

\section{2) Impact of heating rate}

FIGURE III shows the yields of products during the carbonization process of $\mathrm{KB}$ at different heating rate of $5^{\circ} \mathrm{C} / \mathrm{min}, 10{ }^{\circ} \mathrm{C} / \mathrm{min}$ and $20^{\circ} \mathrm{C} / \mathrm{min}$ respectively after holding time of $30 \mathrm{~min}$.

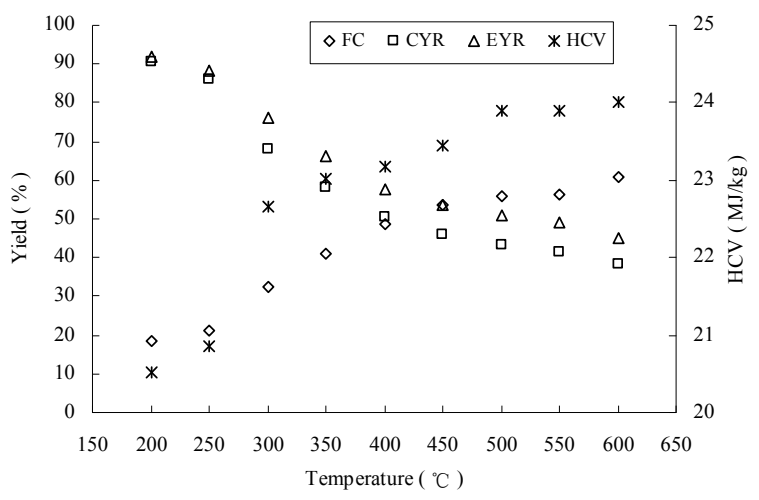

(a) $5^{\circ} \mathrm{C} / \mathrm{min}$

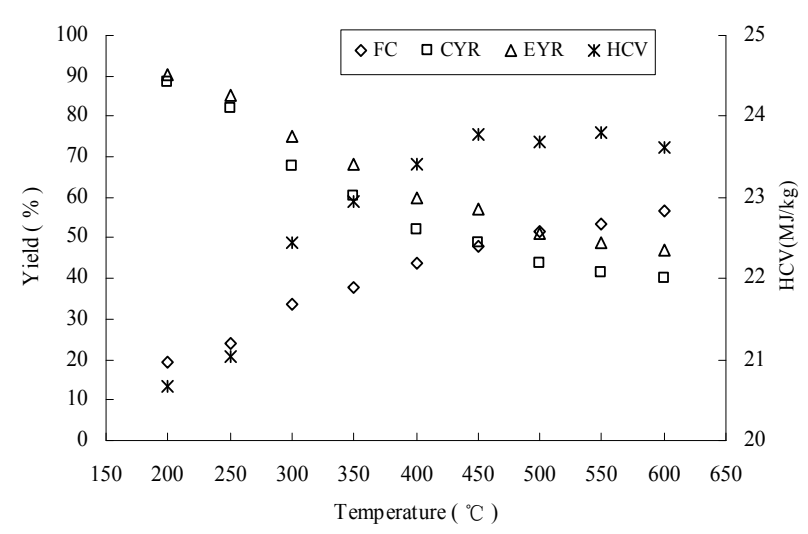

(b) $10^{\circ} \mathrm{C} / \mathrm{min}$

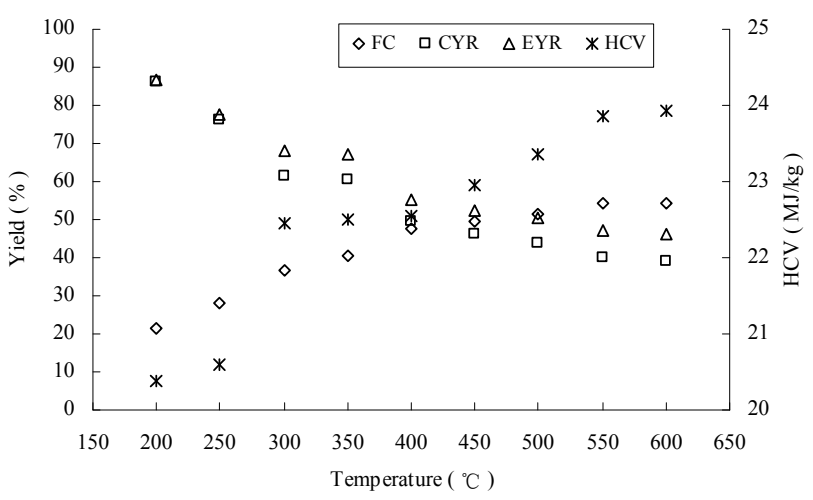

(c) $20^{\circ} \mathrm{C} / \mathrm{min}$

FIGURE II. YIELDS UNDER VARIOUS FINAL HEATING TEMPERATURE

FIGURE III (a) shows the yield of FC at different heating rate. The yield of FC showed an increasing trend at entire preset heating temperature range, but increased faster before $450{ }^{\circ} \mathrm{C}$ than after $450^{\circ} \mathrm{C}$. The reason is that more volatile released before $450^{\circ} \mathrm{C}$ made it harder to be released afterwards. It showed the same increasing sequence before $300^{\circ} \mathrm{C}$ under each heating rate, with the biggest value difference at final heating temperature of $250^{\circ} \mathrm{C}$. Because at the beginning, volatile within $\mathrm{KB}$ began to be released while heated, the faster the temperature increased, the more volatile would be 
released under lower temperature range of $300^{\circ} \mathrm{C}$. So the yield of FC would be increased while volatile released. The more volatile was released, the faster the yield of $\mathrm{FC}$ would increase. The yield of $\mathrm{FC}$ increased fastest at heating rate of $20^{\circ} \mathrm{C} / \mathrm{min}$ before $300^{\circ} \mathrm{C}$. It changed from $21.3 \%$ to $36.59 \%$ while volatile changed from $67.13 \%$ to $46.68 \%$. After final heating temperature of $300^{\circ} \mathrm{C}$, the sequence of increasing rate of $\mathrm{FC}$ began to change. Within the temperature range of $300^{\circ} \mathrm{C}$ to $500^{\circ} \mathrm{C}$, the yield of $\mathrm{FC}$ at heating rate of $5^{\circ} \mathrm{C} / \mathrm{min}$ became the fastest one. This is mainly because more volatile at higher heating rate was released than at higher heating rate. Even if at the same final heating temperature, it was more difficult for the rest volatile at higher heating rate to be released. So the yield of $\mathrm{FC}$ at $20^{\circ} \mathrm{C} / \mathrm{min}$ became the lowest one at the heating temperature of $500^{\circ} \mathrm{C}$ till $600^{\circ} \mathrm{C}$, and the yield of $\mathrm{FC}$ at $5^{\circ} \mathrm{C}$ $/$ min became the fastest one after heating temperature of $350^{\circ} \mathrm{C}$ till $600^{\circ} \mathrm{C}$.

FIGURE III (b) shows the MED at different heating rate. It showed an increasing trend at entire temperature range with a rapid increase between $250{ }^{\circ} \mathrm{C}$ and $300^{\circ} \mathrm{C}$. It showed larger value difference from $350^{\circ} \mathrm{C}$ to $450^{\circ} \mathrm{C}$ between each heating rate. In that temperature range, heating rate of $10{ }^{\circ} \mathrm{C} / \mathrm{min}$ increased fastest, then $5{ }^{\circ} \mathrm{C} / \mathrm{min}$ and $20^{\circ} \mathrm{C} / \mathrm{min}$ in sequence which meant the charcoal at $10^{\circ} \mathrm{C} / \mathrm{min}$ heating rate had the largest energy density per unit mass.

FIGURE III (c) shows the CYR at different heating rate. Within entire heating range, the CYR showed a downward trend because of the release of volatile, with larger value difference between $250{ }^{\circ} \mathrm{C}$ to $300{ }^{\circ} \mathrm{C}$. Then from $350{ }^{\circ} \mathrm{C}$ to $600^{\circ} \mathrm{C}$, it showed little value difference between each heating rate.

FIGURE III (d) shows the EYR at different heating rate. It showed the similar downward trend with CYR. Within entire heating range, the EYR showed a downward trend with larger value difference between $250^{\circ} \mathrm{C}$ to $300^{\circ} \mathrm{C}$. Then from $350^{\circ} \mathrm{C}$ to $600^{\circ} \mathrm{C}$, it also showed little value difference between each heating rate.

\section{Analysis of Optimum Carbonization Conditions}

From the analysis of impact factors on carbonization aforementioned, both final heating temperature and heating rate have impact on the process. Set MED as the most important evaluation index, then EYR , CYR and FC in sequence, and compare the proximate analysis with typical soft coal, FIGURE IV shows the change of each index at different final heating temperature under $10^{\circ} \mathrm{C} / \mathrm{min}$ heating rate, then carbonization process at $450^{\circ} \mathrm{C}$ final heating was the best result, which meant in comprehensive consideration, sample KB-450-10 matched each index best under the preset experimental conditions.

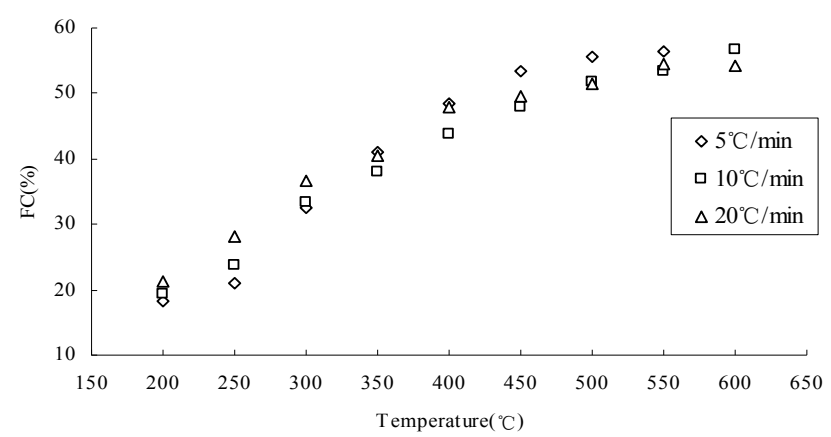

(a) fixed carbon

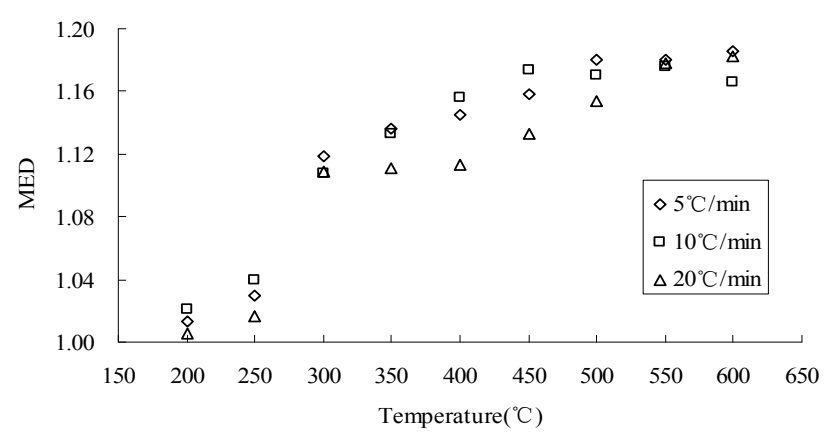

(b) mass energy density

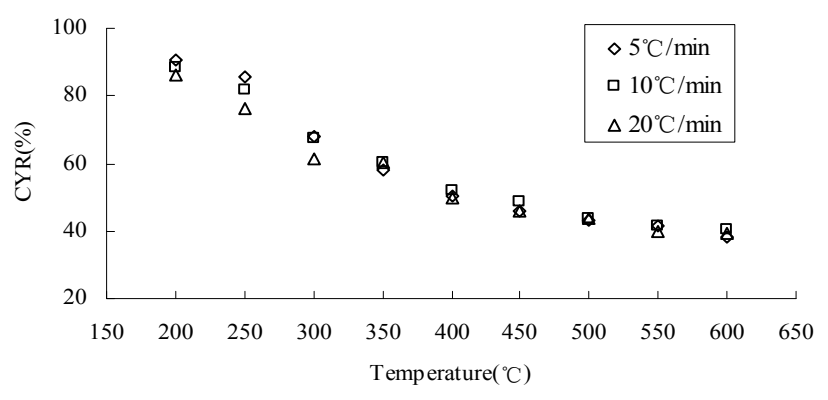

(c) charcoal yield rate

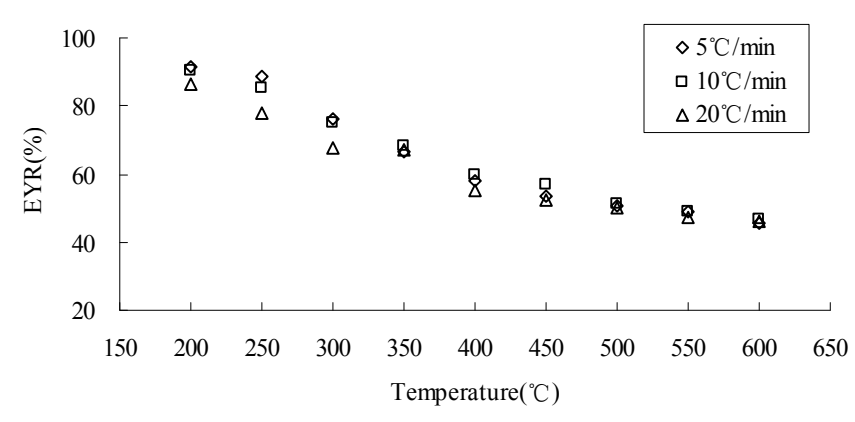

(d) energy yield rate

FIGURE III. YIELDS UNDER DIFFERENT HEATING RATE 


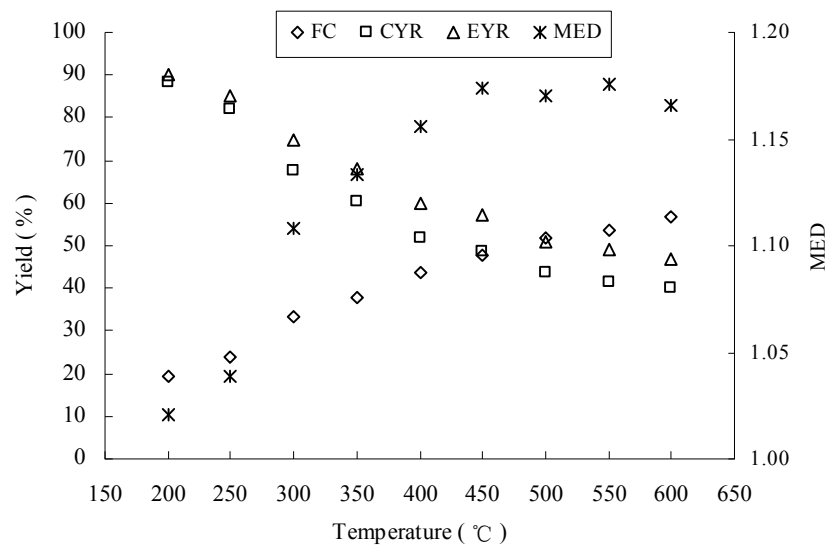

FIGURE IV. CHANGE OF INDEX AT $10^{\circ} \mathrm{C} / \mathrm{min}$ HEATING RATE

\section{CONCLUSION}

From the analysis of impact factors on carbonization aforementioned, both final heating temperature and heating rate have impact on the process. Both FC and MED increased with the increase of final heating temperature, but showed diffenrent increasing rate at different heating rate. Both CYR and EYR decreased with the increase of final heating temperature, but showed larger difference in value at lower final heating temperature. Set MED the most important evaluation index, then EYR, CYR and FC in sequence, then carbonization process at $450^{\circ} \mathrm{C}$ final heating was the best result, which meant sample KB-450-10 showed the similar thermalchemical properties with typical soft coal, and matched each indicator best in a comprehensive consideration under the preset experimental conditions.

\section{ACKNOWLEDGMENT}

The authors would like to thank the State Scholarship Fund of China Scholarship Council (CSC), Special Fund for Agroscientific Research in the Public Interest (No.20150313506), Science and Technology Project of Jilin Province (No.20140204024NY) for the funding provided.

\section{REFERENCES}

[1] J. Chang, Dennis Y.C. Leung, C.Z. Wu, Z.H. Yuan, "A review on the energy production, consumption, and prospect of renewable energy in China," Renewable \& Sustainable Energy Reviews, vol.7, 2003, pp. 453-468.

[2] Hengyun MA, Les Oxley, John Gibson, Wen Li, “A survery of China's renewable energy economy," Renewable \& Sustainable Energy Reviews, vol.14, 2010, pp. 438-445.

[3] N.P.K. Nielsen, J.K. Holm, C. Felby, "Effect of fiber orientation on compression and frictional properties of sawdust particles in fuel pellet production,” Energy \& Fuels, vol.23, 2009, pp. 3211-3216.

[4] H. Abdullah, H. Wu, "Biochar as a fuel: 1. Properties and grindability of biochars produced from the pyrolysis of Mallee wood under slowheating conditions," Energy \& Fuels, vol.23, 2009, pp. 4174-4181.

[5] H. Abdullah, K.A. Mediaswanti, H. Wu, "Biochar as a fuel: 2 . Significant differences in fuel quality and ash properties of biochars from various biomass components of Mallee trees," Energy \& Fuels, vol.24, 2010, pp. 1972-1979.
[6] .K.N. Finney, V.N. Sharifi, J. Swithenbank, "Fuel Pelletization with a binder: part I-Identification of a suitable binder for spent mushroom compost-coal tailing pellets," Energy \& Fuels, vol.23, 2009, pp. 31953202 .

[7] Df Arias B, Pevida C, Fermoso J, Plaza MG, Rubeira F, Pis JJ. "Influence of torrefaction on the grindability and reactivity of woody biomass," Fuel Process Technol, vol.89, 2008, pp.169-75..

[8] J.K Holm, U.B. Henriksen, J.E. Hustad, L.H. Sorensen, "Toward an understanding of controlling parameters in softwood and hardwood pellets production," Energy \& Fuels, vol.20, 2006, pp. 2686-2694.

[9] Axel F, Felix Zr. "Heat of reaction measurements for hydrothermal carbonization of biomass," Bioresource Technology, vol.102(16), 2011, pp.7595-7598.

[10] Burhenne L, Messmer J, Aicher T, et al. "The effec of the biomass components lignin, cellulose and hemicellulose on TGA and fixed bed prolysis," Journal of Analytical and Applied Pyrolysis, vol.101, 2013, pp.177-184. 